Reprod. Nutr. Dévelop., 1985, 25 (5), 851-860.

\title{
The influence of an essential fatty acid deficient-diet on the reproductive performance of female rats
}

\author{
Iris A. PARLANTI, Liliana C. ORELLANA
}

$1^{\circ}$ Cátedra de Histología, Embriologia y Genética, Facultad de Ciencias Médicas,

Universidad Nacional de Córdoba and CEBYD-CONICET, Casilla de Correo 220, 5000 Córdoba, Argentina.

Summary. Several parameters of the reproductive function were studied in albino rats of the Wistar strain fed an essential fatty acid-deficient (EFAD) diet, a linoleic acid-sufficient (EFAS) diet or a commercial diet (CD).

The frequency of irregular estrous cycles, with an increased incidence of prolonged diestrus, was significantly higher in EFAD and EFAS groups than in the CD group. There were no significant differences between EFAD and EFAS rats in any of the estrous cycle parameters studied. The EFAD rats showed the following changes in reproductive performance in respect to EFAS and CD dams : prolonged period of gestation, reduced litter size and increased pup mortality during delivery and the first 48 neonatal hours. From this time to weaning, EFAD and EFAS pups had a similar rate of mortality and were different in this respect from the CD group.

These results support previous reports indicating that linoleic acid is essential to the maintenance of normal pregnancy and the survival of newborn rats. Nevertheless, we cannot conclude that impairment of the estrous cycle and sucking mortality until weaning were primarily due to the absence of linoleic acid in the maternal diet. The possible role of $\alpha$-linolenic acid in the reproductive function is discussed.

\section{Introduction.}

It is well known that polyunsaturated fatty acids (PUFA) play a role in the maintenance of different physiological functions (Aaes-Jørgensen, 1961 ; Durand, Pascal and Gounelle de Pontanel, 1979 ; Monis et al., 1981 ; Rivers and Frankel, 1981). Burr and Burr (1930) originally reported that certain PUFA prevented and cured some of the signs and symptoms seen in rats fed diets almost devoid of these lipid constituents. These authors posited three PUFA : linoleic acid $(18: 2$ $\mathrm{n}-6)$, arachidonic acid $(20: 4 \mathrm{n}-6)$ and $\alpha$-linolenic acid $(18: 3 n-3)$ to be essential to rats. At present, linoleic and arachidonic acids are recognized as essential nutrients, but the essentiality of $\alpha$-linolenic acid is less apparent (Rivers and Frankel, 1981 ; Tinoco, 1982). 
It has been shown in previous studies that reproductive failure always ensues in female rats which have grown to maturity on an essential fatty acid-deficient (EFAD) diet (Burr and Burr, 1930; Evans, Lepkovsky and Murphy, 1934 ; Kummerow, Pan and Hickman, 1952). It has also been reported that irregular ovulation and prolonged diestrus are characteristic of the estrous cycle of EFAD rats (Turpeinen, 1938 ; Panos and Finerty, 1953 ; Hafiez, 1974) and it has long been known that lack of dietary essential fatty acids (EFA) during pregnancy results in infertility, prolonged gestation, excessive hemorrhaging at parturition and a high incidence of stillbirth (Quackenbush, Kummerow and Steenbock, 1942 ; Deuel, Martin and Alfin-Slater, 1954 ; Alfin-Slater et al., 1965). On the other hand, the addition of linoleic acid or its metabolic products, such as arachidonic acid or prostaglandin $E_{2}$, to the EFAD diet have been shown to prevent impairment of the reproductive function (Burr and Burr, 1930 ; AlfinSlater et al., 1965 ; Tinoco et al., 1971 ; Hafiez, 1974).

The present paper compares changes in the reproductive function of rats fed semisynthetic diets, either lacking EFA or sufficient in linoleic acid, with the reproductive function in rats fed a commercial diet. This data should provide more evidence concerning the changes primarily due to the absence of linoleic acid in the diet.

\section{Material and methods.}

Animals. - Virgin female rats of the Wistar strain were kept under alternate light/dark periods of $12 \mathrm{~h}$ each. The animals were divided into three groups, each fed a different diet ad libitum after weaning. Group 1 (61 rats) received an EFAdeficient (EFAD) diet (Farias, Goldemberg and Trucco, 1970) ; group 2 (60 rats) received the same EFAD diet in which $5 \%$ corn oil, a source of linoleic acid, replaced $5 \%$ wheat starch (table 1). This diet was called « sufficient in essential

TABLE 1

Composition of semisynthetic diets.

\begin{tabular}{|c|c|c|}
\hline & EFAD & EFAS \\
\hline Casein & $16.1 \%$ & $16.1 \%$ \\
\hline$\ldots \ldots \ldots$ & $41.3 \%$ & $41.3 \%$ \\
\hline Wheat starch & $38.7 \%$ & $33.7 \%$ \\
\hline Salt mixtures $\left({ }^{1}\right)$ & $3.6 \%$ & $3.6 \%$ \\
\hline Vitamins $\left(^{2}\right) \ldots \ldots \ldots \ldots \ldots \ldots$ & $0.3 \%$ & $0.3 \%$ \\
\hline Corn oil $\left(^{3}\right) \ldots \ldots \ldots \ldots \ldots \ldots$ & - & $5.0 \%$ \\
\hline
\end{tabular}

(1) Salt mixtures per kilogram of food (in $\mathrm{g}$ ) : calcium carbonate, 13.57; potassium chloride, 2.80 ; mono-potassium orthophosphate, di-H, 5.30 ; magnesium carbonate, 0.62 ; magnesium sulphate, 0.40 ; sodium chloride, 1.72 ; ferric chloride, 0.35 ; (and in $\mathrm{mg}$ ) : potassium iodide, 0.20 ; manganese chloride, 0.87 ; sodium fluoride, 2.50 ; aluminium potassium sulphate, 0.42 ; copper sulphate, 2.25. The concentration of zinc was approximately $14 \mathrm{mg} / \mathrm{kg}$ of diet as determined by atomic absorption.

(2) Vitamins (mg/1000 $\mathrm{g}$ of food) : nicotinamide, 100 ; choline chloride, 1000 ; inositol, 200 ; pyridoxine hydrochloride, 5 ; thiamine hydrochloride, 5 ; riboflavin, 5 ; folic acid, 5 ; calcium pantothenate, 10 ; biotin, 0.05 ; cianocobalamine, 0.05 ; menadione, 0.25 ; retynil acetate, $17.000 \mathrm{IU}$; ergocalcipherol, 6 and tocopheryl acetate, 200.

(3) Fatty acid composition of corn oil : $16: 0,15.7 \pm 1.3 ; 18: 0,2.4 \pm 0.2 ; 18: 1 \mathrm{n}-9$, $31.7 \pm 1.3 ; 18: 2 n-6,46.4 \pm 1.7 ; 18: 3 n-3,0.8 \pm 0.2$. Results are expressed as mean \pm S.E.M. of 5 determinations from separate samples. 
fatty acids " (EFAS); group 3 (118 rats) was fed a commercial diet (CD) containing the following ingredients : crude protein $18.5 \%$, total lipids $7.3 \%$, ash $8 \%$, crude fiber $6 \%$. Dietary fatty acid methyl esters were analysed by gasliquid chromatography; the values obtained are shown in table 2.

Around 10 weeks of age, group 1 (EFAD) animals showed symptoms of EFA deficiency such as weight loss, dermatitis of the tail and dorse of the legs (AaesJørgensen, 1961 ; Holman, 1960).

TABLE 2

Fatty acid composition of dietary lipids (\%).

\begin{tabular}{lrrr}
\hline & EFAD & \multicolumn{1}{c}{ EFAS } & \multicolumn{1}{c}{ CD } \\
\hline $14: 0$ & $5.9 \pm 0.4$ & $2.0 \pm 0.3$ & $1.5 \pm 0.1$ \\
$14: 1$ & $1.3 \pm 0.3$ & $0.3 \pm 0.1$ & $0.5 \pm 0.1$ \\
$16: 0$ & $32.9 \pm 2.0$ & $20.5 \pm 1.1$ & $23.1 \pm 1.0$ \\
$16: 1$ & $3.3 \pm 0.2$ & $0.2 \pm 0.1$ & $2.9 \pm 0.2$ \\
$18: 0$ & $14.1 \pm 0.8$ & $5.4 \pm 0.4$ & $9.0 \pm 0.5$ \\
$18: 1 \mathrm{n}-9$ & $23.4 \pm 1.3$ & $29.8 \pm 0.8$ & $26.4 \pm 0.8$ \\
$18: 2 \mathrm{n}-6$ & $10.6 \pm 0.9$ & $36.9 \pm 1.6$ & $32.4 \pm 1.5$ \\
$18: 3 \mathrm{n}-3$ & $1.3 \pm 0.2$ & $1.0 \pm 0.2$ & $2.7 \pm 0.3$ \\
Total lipids & 1.2 & 5.7 & 7.3
\end{tabular}

Fatty acid data are expressed as mean \pm SEM of five determinations from separate samples. Only the principal fatty acids are shown and, thus, totals are less than $100 \%$.

\section{Experimental design.}

1. Estrous cycle. - When the rats were 3 months old, vaginal secretions were collected daily for 15 days from 10.00 to 12.00 a.m. and smeared on glass slides. The samples were stained with hematoxylin and eosin. Three stages of the estrous cycle were distinguished: proestrus, estrus and diestrus, the last one comprises diestrus I (metestrus) and diestrus II. Rats in which we observed three consecutive regular 4-day estrous cycles composed the "regular cycle " (RC) group. Those in which regular cycles alternated with even one irregular cycle were included in the "irregular cycle » (IC) group. The number of regular cycles and short cycles (less than 4 days long) and the prolongation of cycle stages were studied in the IC group for a 15 day period.

2. Reproductive function. - To evaluate reproductive performance, 37 EFAD, 29 EFAS and $44 \mathrm{CD}$ rats were chosen at random from the lot used. Proestrous female rats were placed overnight in a cage with a young male of proven fertility fed the commercial diet. The observation of spermatozoa in the vaginal fluid indicated the first day of pregnancy. Length of pregnancy, maternal mortality, litter size and pup mortality were recorded in these groups. Rats which showed spermatozoa in the vaginal fluid as often as three times without subsequent pregnancy were considered sterile.

Statistical analysis. - The G-association test and Fisher's exact test were used to compare frequency data (Sokal and Rohlf, 1969). The number of estrous cycles, 
length of cycle stages and litter size were tested by one-way analysis of variance. Pup survival was analysed by the Logrank-test for survivorship data (Peto et al., 1977).

\section{Results.}

1. Estrous cycle. - The percentage of rats having regular estrous cycles was not different in the EFAD and EFAS groups. In the CD group, the percentage of animals having regular cycles was significantly higher than in the EFAD $(P<<0.0005)$ and EFAS $(P<0.01)$ groups (table 3$)$.

TABLE 3

Effect of the diets on estrous cycle regularity.

\begin{tabular}{lccc}
\hline Diet & $\begin{array}{c}\text { Number } \\
\text { of animals }\end{array}$ & $\begin{array}{c}\text { (Regular cycle } \\
\text { group }\end{array}$ & $\begin{array}{c}\text { " Irregular cycle " } \\
\text { group }\end{array}$ \\
\hline EFAD & 61 & $13(21 \%)$ & $48(79 \%)$ \\
EFAS & 60 & $19(32 \%)$ & $41(68 \%)$ \\
CD & 118 & $62(53 \%)$ & $56(47 \%)$ \\
\hline
\end{tabular}

Significance ( $G$ » association test): EFAD vS EFAS : not significant; EFAD vs CD : $\mathrm{p}<<0.0005$; EFAS vs CD : $\mathrm{p}<0.01$.

The IC rats fed the commercial diet showed more regular cycles $(1.64 \pm 0.13)$ during the 15-day control period than EFAD $(1.02 \pm 0.12 ; P<0.005)$ and EFAS $(1.22 \pm 0.15 ; P<0.05)$ rats; no significant difference was noted between EFAD and EFAS animals. The incidence of short cycles was not significantly different in the three IC groups (EFAD : 16/48; EFAS : 8/41;CD : 17/56). The length of proestrus and estrus was not diet-dependent. Instead, diestrus was longer in EFAD and EFAS rats than in the CD group $(P<0.005$ and $P<0.025$, respectively), but the difference between the EFAD and EFAS groups was not significant (fig. 1).

2. Reproductive function. - Matings necessary to ensure pregnancy were : EFAD, $1.40 \pm 0.12$; EFAS, $1.44 \pm 0.12$ and $C D ; 1.54 \pm 0.14$; there was no significant difference among the three groups. We found only 4 sterile rats and they belonged to the EFAD group.

The period of gestation was significantly prolonged in EFAD dams compared to EFAS $(P<0.025)$ and $C D(P<0.05)$ animals, but no differences were found between EFAS and CD rats. Pregnancy lasted more than 22 days in $55 \%(17 / 31)$ of EFAD, $23 \%(6 / 26)$ of EFAS, and $30 \%(12 / 41)$ of CD rats. Maternal mortality during parturition was not significantly different among the three groups (EFAD : 2/33, EFAS : 3/29, CD : 3/44).

The average size of EFAD litters was significantly smaller than that of the EFAS $(P<0.05)$ and $C D(P<0.005)$ groups. No significant differences were found between EFAS and CD litter size (table 4). The incidence of stillbirth and 


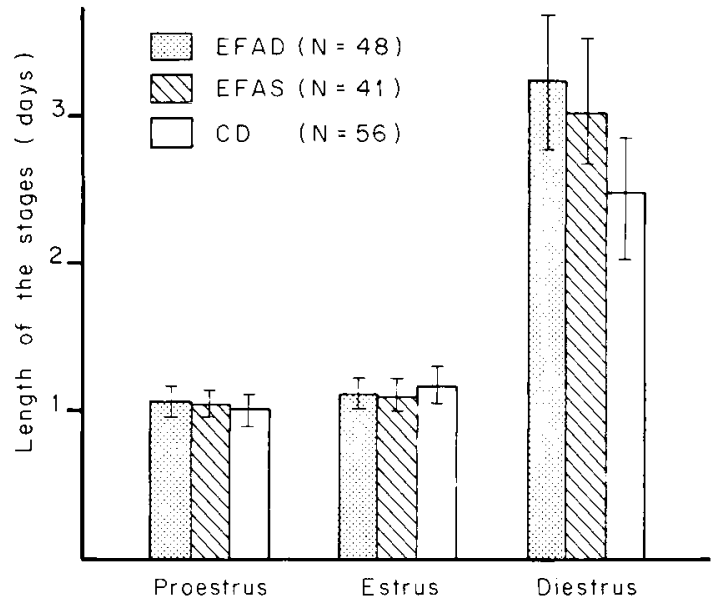
group.

FIG. 1. - Average length of the stages of the estrous cycle in rats of the "irregular cycle "

$\mathrm{N}$ : number of rats.

Mean \pm least-significant difference $(5 \%)$.

Significant results by the analysis of the variance (one-way): diestrus: EFAD vs CD, $\mathrm{p}<0.005$; EFAS $v s \mathrm{CD}, \mathrm{p}<0.025$.

TABLE 4

Effect of the diet on litter size.

\begin{tabular}{lcc}
\hline Diet & $\begin{array}{c}\text { Number } \\
\text { of mothers }\end{array}$ & $\begin{array}{c}\text { Litter size } \\
\text { (Mean } \pm \text { SEM) }\end{array}$ \\
\hline EFAD & 31 & $8.55 \pm 0.41$ \\
EFAS & 26 & $10.08 \pm 0.55$ \\
CD & 41 & $10.68 \pm 0.48$ \\
\hline
\end{tabular}

Significance (analysis of the variance : one-way) : EFAD vs EFAS : $p<0.05$; EFAD vs CD ; $p<0.005$; EFAS vs CD : not significant.

newborn mortality was significantly higher in EFAD (37/264) than in EFAS $(3 / 262 ; P<<0.0005)$ and $C D(9 / 438 ; P<<0.0005)$ litters. No significant differences were noted in this respect between EFAS and $C D$ litters. Figure 2 shows that the mortality of EFAD pups up to $48 \mathrm{~h}$ after delivery was greater than in the EFAS ( $P<<0.0005)$ and $C D$ ( $P<<0.0005)$ pups. There was no significant difference in the mortality rate between the EFAS and $C D$ groups during this period. The survival rate was not different in either EFAD or EFAS pups after the first 48 neonatal hours (fig. 2). Yet, both EFAD and EFAS young were different in this respect from $C D$ pups ( $P<<0.0005$ for both). The percentage of offspring alive at weaning was: EFAD, $40 \%(106 / 264)$; EFAS, $52 \%(136 / 262) ; C D, 88 \%(387 / 438)$ ( $P<<0.0005$ for both EFAD and EFAS pups compared to $C D$ pups). 


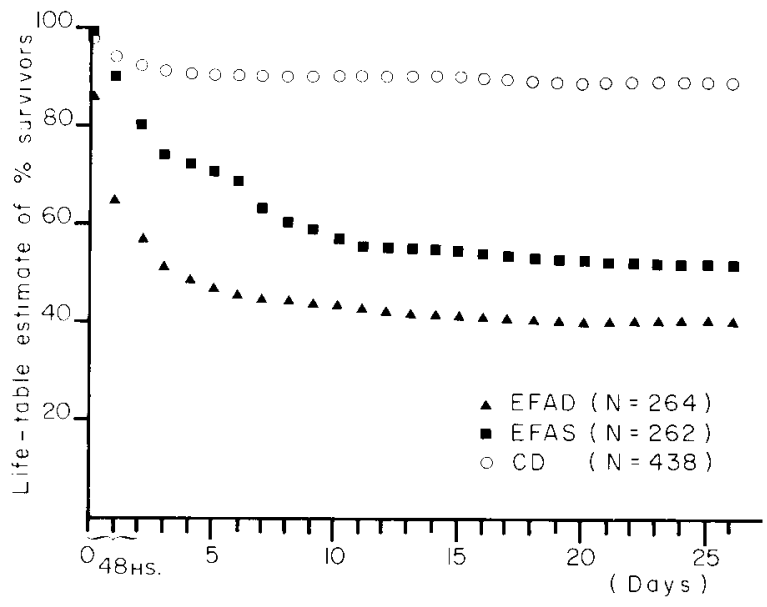

FIG. 2. - Life-table estimate of survivor percentage of EFAD, EFAS and CD offspring. $\mathrm{N}$ : number of offspring at birth.

Significance by Logrank test : EFAD vs EFAS : $p<<0.0005$; EFAD vs CD : $p<<0.0005$; EFAS VS CD : $\mathrm{p}<<0.0005$.

$\%$ survivors (48 h of life) : EFAD vs EFAS : $p<<0.0005$; EFAD vs CD : $p<<0.0005$; EFAS vs CD : not significant (NS).

$\%$ survivors (after $48 \mathrm{~h}$ of life): EFAD vs EFAS: NS; EFAD vs CD : $p<<0.0005$; EFAS vs CD : $\mathbf{p}<<0.0005$.

\section{Discussion.}

The results presented here support earlier reports indicating that altered patterns of cyclicity, with an increased incidence of prolonged diestrus, are widespread in EFA-deficient rats (Turpeinen, 1938; Panos and Finerty, 1953). However, we found that the addition of $5 \%$ corn oil, a source of linoleic acid, to the EFAD diet was not enough to obtain an unimpaired estrous cycle since significant differences between the EFAD and EFAS groups could not be shown for any of the estrous cycle parameters studied. This is relevant in view of the data indicating that many symptoms of EFA deficiency, such as impairment of the estrous cycle, may indeed be prevented if the diet is supplemented with linoleic or arachidonic acid or prostaglandin $E_{2}$ (Burr and Burr, 1930; Hafiez, 1974). Therefore, we cannot conclude that the loss of cyclicity found in our EFAD rats was primarily due to the absence of dietary linoleic acid.

Our findings also show that, as regards all the estrous cycle parameters studied, both the EFAD and the EFAS group differed from the animals fed the commercial diet. It remains to be determined whether factors other than $n-6$ fatty acids can account for the these results; it must be noted that the analysis of the fatty acid composition of the diets (table 2) indicates that the level of $\alpha$-linolenic acid was lower in both the EFAD and the EFAS diet. This observation suggests that an adequate dietary supply of $\alpha$-linolenic acid is necessary to obtain an unimpaired estrous cycle in rats. Although linoleic acid is recognized as an 
essential nutrient, the essentiality of $\alpha$-linolenic acid is less apparent (Crawford, Hassan and Rivers, 1978 ; Rivers and Frankel, 1981 ; Tinoco, 1982) and, to our knowledge, there is no bibliographical evidence suggesting that $n-3$ fatty acids are required to maintain a normal pattern of estrous cycles. However, changes in other physiological functions have been observed in animals selectively deprived of n-3 fatty acids for prolonged periods (Castell et al., 1972 ; Benolken, Anderson and Wheeler, 1973 ; Lamptey and Walker, 1976). On the other hand, the present results might not be due to $n-3$ deficiency alone, but also to a change in the linoleic acid/linolenic acid ratios in the diets. These ratios were very different (table 2). It has been shown that a variation in the dietary linoleic/linolenic acid ratio produces more marked changes in tissue FA composition than a variation in dietary EFA concentration (Alling et al., 1972).

In contrast with other authors (Evans, Lepkovsky and Murphy, 1934 ; Kummerow, Pan and Hickman, 1952), we found that sterility and maternal mortality during parturition were not significantly different among the three groups. In agreement with previous studies, our data indicate that a lack of dietary n-6 fatty acids results in a prolonged gestation, reduced litter size and increased pup mortality during delivery and the first 48 neonatal hours lQuackenbush, Kummerow and Steenbock, 1942; Kummerow, Pan and Hickman, 1952 ; Alfin-Slater et al., 1965). Since linoleic acid is the substrate for the synthesis of several prostanoids, a deficient production of these compounds cannot be excluded in EFAD rats. It has been suggested that prostaglandins (PGs) may have a role in the termination of pregnancy by lowering serum progesterone levels by a luteolytic mechanism (Labhsetwar, 1974 ; Holinka, Tseng and Finch, 1978). An important cause of reduced litter size in EFAD rats might be implantation failure due to a decrease in local PGs production (Brown, Gosden and Poyser, 1984). Another cause could be increased reabsorption and abortion (Maeder, 1937; Kummerow, Pan and Hickman, 1952). The high neonatal mortality in the EFAD litter could result from developmental abnormalities (Sinclair and Crawford, 1973) or fetal distress caused by prolonged gestation or impairment of the softening of the uterine cervix at term. This suggestion is supported by the findings of Holinka, Tseng and Finch (1978) who demonstrated that stillbirth rate is proportional to delay in parturition. On the other hand, Hillier and Wallis (1982) showed that PGs and arachidonic acid are important in determining the inflexibility of the uterine cervix at birth.

In conclusion, the present results confirm and extend previous observations and show that linoleic acid is essential to the maintenance of normal pregnancy and to the survival of newborn rats.

After the first 48 neonatal hours, the pups of EFAD and EFAS rats had a significantly higher death rate than those of CD dams. Moreover, both EFAD and EFAS young had a similar survival rate from that time to weaning. The interpretation of these findings is not clear, but it is possible that imbalances in the components of the semi-synthetic diets, such as protein or zinc, could explain these results. Nevertheless, it may be that low levels of $\alpha$-linolenic acid or altered linoleic acid/linolenic acid ratios in the semi-synthetic diets impaired pup 
development (Sanders and Naishmith, 1980 ; Morgan, Oppenheimer and Winick, 1981) and/or normal lactation (Sinclair and Crawford, 1972 ; François, 1983). Other workers have observed higher mortality and lower growth rate in the pups of linolenate-deficient rats (François, Pascal and Durand, 1980). On the other hand, it is known that linoleic and $\alpha$-linolenic acids and their long-chain derivates are important components of structural lipids in many tissues, notably the brain, and are accumulated and metabolized in this organ during the time when the pups depend on maternal nutrition (Alling et al., 1972; Menon, Moore and Dhopeshwarkar, 1981 ; Purvis et al., 1983).

Available evidence indicates that a deficiency of nutrients such as PUFA may influence certain ageing processes (Guarnieri and Johnson, 1970 ; Durand, Pascal and Gounelle de Pontanel, 1979). It is interesting to note that changes in the reproductive function, as found in our EFAD rats, are similar to those observed in ageing female rodents fed a commercial diet (Talbert, 1968). The age-related decline in the reproductive capacity of rats and mice is manifested by a decrease in litter size, and increase in resorption and stillbirth, and a marked prolongation of pregnancy (Jones and Krohn, 1961; Harman and Talbert, 1974; Holinka, Tseng and Finch, 1979). This similarity suggests that essential fatty acid deficiency might hasten the ageing process of the reproductive system. Brown, Gosden and Poyser (1984) have demonstrated that PGs production is reduced in the uteri of aged rats, and they suggested that decreased PG synthesizing ability might be a generalized effect of ageing. In addition, 6-desaturation of linoleic acid and $\alpha$-linolenic acid have also been reported to decrease with age (Peluffo and Brenner, 1974).

Reçu en mai 1984. Accepté en juin 1985.

Acknowledgments. - This work was supported by CONICET, Argentina. The authors are indebted to Bioch. Mirta A. Valentich for carrying out the liquid-gas chromatography, to Miss Susana Gutierrez for typing the manuscript and to Mr José Hiza for animal care.

Résumé. Influence d'un régime carencé en acides gras essentiels sur les performances de reproduction chez la ratte.

L'objet de ce travail est d'étudier, chez le rat (Wistar), plusieurs paramètres de la fonction reproductrice, sous l'influence de différentes conditions nutritionnelles : régime déficient en acides gras essentiels (EFAD), régime suffisant en acide linoléique (EFAS), et régime commercial (CD).

Chez les groupes EFAD et EFAS on observe une augmentation significative de la fréquence des cycles œstraux irréguliers - avec allongement significatif du dicestrus - par rapport au groupe $C D$. Entre les groupes EFAD et EFAS il n'y a pas de différences significatives dans les paramètres du cycle œestral étudiés.

Chez les rats EFAD, on observe les altérations suivantes de la fonction de reproduction : prolongement de la gestation, diminution du nombre moyen de fœtus par portée et augmentation de la mortalité des nouveau-nés durant l'accouchement et pendant les premières 48 heures de vie postnatale. La probabilité de survie de la portée après ce 
temps - jusqu'au sevrage - est semblable chez les groupes EFAD et EFAS, et significativement inférieure par rapport au groupe CD.

En conclusion, les données obtenues dans ce travail appuient I'hypothèse que l'acide linoléique est essentiel pour maintenir la normalité de la gestation, ainsi que pour assurer la survie des nouveau-nés. Cependant, on ne peut pas conclure que l'altération du cycle œstral et la mortalité de la portée pendant la lactation sont dus principalement à l'absence de l'acide linoléique du régime maternel. Un rôle possible de l'acide alpha linolénique dans la fonction de reproduction est discuté.

\section{References}

AAES-JøRGENSEN E., 1961. Essential fatty acids. Physiol. Rev., 41, 1-51.

ALFIN-SLATER R. B., MORRIS R. S., HANSEN H., PROCTOR F., 1965. Effects of non-essential fatty acids on essential fatty acid deficiency. J. Nutr., 87, 168-172.

ALLING C., BRUCE $\AA$. ., KARLSSON I., SAPIA O., SVENNERHOLM L., 1972. Effect of maternal essential fatty acid supply on fatty acid composition of brain, liver, muscle and serum in 21 day-old-rats. J. Nutr., 102, 773-782.

BENOLKEN R. M., ANDERSON R. E., WHEELER T. G., 1973. Membrane fatty acids associated with the electrical response in visual excitation. Science, 182, 1253-1254.

BROWN C., GOSDEN R. G., POYSER N. L., 1984. Effects of age and steroid treatment on prostaglandin production by the rat uterus in relation to implantation. J. Reprod. Fertil., 70, 649-656.

BURR G. O., BURR M. M., 1930. On the nature and the role of the fatty acids essential in nutrition. J. biol. Chem., 86, 587-621.

CASTELL J. D., SINNHUBER R. D., LEE D. J., WALES J. H., 1972 . Essential fatty acids in the diet of rainbow trout (Salmo gairdneri) : Physiological symptoms of EFA deficiency. J. Nutr., $102,87-92$

CRAWFORD M. A., HASSAN A. G., RIVERS J. P. W., 1978. Essential fatty acid requirements in infancy. Am. J. clin. Nutr., 31, 2181-2185.

DEUEL H. J. Jr., MARTIN C. R., ALFIN-SLATER R. B., 1954. The effect of fat level of the diet on general nutrition. XII. The requirement of essential fatty acids for pregnancy and lactation. J. Nutr., 54, 193-199.

DURAND G., PASCAL G., GOUNELLE de PONTANEL H., 1979. Traitement de l'hypercholestérolémie chez le rat mâle par introduction dans la ration d'huile de soja supplémentée ou non par de l'huile de sardine. Ann. Nutr. Alim., 33, 687-706.

EVANS H. M., LEPKOVSKY S., MURPHY E. A., 1934. Vital need of the body for certain unsaturated fatty acids. IV. Reproduction and lactation upon fat free-diets. J. biol. Chem., 106, 431440.

FARIAS R. N., GOLDEMBERG A. L., TRUCCO R. L., 1970. The effect of fat deprivation on the allosteric inhibition by fluoride of the $\left(\mathrm{Mg}^{2+}\right)$-ATPase and $\left(\mathrm{Na}^{+} \mathrm{K}^{+}\right)$-ATPase from rat erithrocytes. Archiv. Biochem. Biophys., 139, 38-44.

FRANÇOIS M., 1983. Effets de la carence en acide $\alpha$-linolénique sur la reproduction et le développement du rat. Th. Doct. $3^{\mathrm{e}}$ cycle, Univ. Paris VI.

FRANÇOIS M., PASCAL G., DURAND G., 1980. Effets de la carence alimentaire en acide $\alpha$-linolénique chez le rat. Ann. Nutr. Alim., 34, 443-450.

GUARNIERI M., JOHNSON R. M., 1970. The essential fatty acids. Adv. Lipid Res., 8, 115-174.

HAFIEZ A. A., 1974. Prostaglandin $E_{2}$ prevents impairment of fertility in rats fed a diet deficient in essential fatty acids. J. Reprod. Fertil., 38, 273-286.

HARMAN S. M., TALBERT G. B., 1974. Effect of maternal age on synchronization of ovulation and mating and on tubal transport of ova in mice. J. Geront., 29, 493-498.

HILLIER K., WALLIS R. M., 1982. Collagen solubility and tensile properties of the rat uterine cervix in late pregnancy: effects of arachidonic acid prostaglandin $F_{2 \alpha}$.J. Endocr., 95, 341-347.

HOLINKA C. F., TSENG Y. C., FINCH C. E., 1978. Prolonged gestation, elevated preparturitional plasma progesterone and reproductive aging in C57BL/6J mice. Biol. Reprod, 19, 807-816. 
HOLINKA C. F., TSENG Y. C., FINCH C. E., 1979. Reproductive aging in C57BL/6J mice : plasma progesterone, viable embryos and resorption frequency throughout pregnancy. Biol. Reprod., 20, 1201-1211.

HOLMAN R. T., 1960. The trienoic/tetraenoic acid ratio has proved to be a convenient expression of essential fatty acid status. J. Nutr., 70, 405-410.

JONES E. O., KROHN P. L., 1961. The relationships between age, numbers of oocytes and fertility in virgin and multiparous mice. J. Endocr., 21, 469-495.

KUMMEROW F. A., PAN H. P., HICKMAN H., 1952. The effect of dietary fat on the reproductive performance and the mixed fatty acid composition of the fat-deficient rats. J. Nutr., 46, 489-498.

LABHSETWAR A. P., 1974. Prostaglandins and the reproductive cycle. Fed. Proc., 33, 61-77.

LAMPTEY M. S., WALKER B. L., 1976. A possible essential role for dietary linolenic acid in the development of the young rat. J. Nutr., 106, 86-93.

MAEDER E. C., 1937. The effect of fat in simplified diets on reproductive organs of the female albino rat during gestation. Anat. Rec., 70, 73-88.

MENON N. K., MOORE C., DHOPESHWARKAR G. A., 1981. Effect of EFA deficiency on maternal, placental and fetal rat tissues. J. Nutr., 111, 1602-1610.

MONIS B., EYNARD A. R., KALINEC F., VALENTICH M. A., PARLANTI I. A., 1981. Recent observations on the pathobiology of essential fatty acid deficient rats, 179-195. In BAZAN N. G., PAOLETTI R., IACONO J. M. New trends in nutrition, lipid research and cardiovascular diseases. A.R. Liss Inc., N.Y.

MORGAN B. L. G., OPPENHEIMER J., WINICK M., 1981. Effects of essential fatty acid deficiency during late gestation on brain $\mathrm{N}$-acetylneuraminic acid metabolism and behaviour in the progeny. Br. J. Nutr., 46, 223-230.

PANOS T. C., FINERTY J. C., 1953. Effects of a fat-free diet on growing female rats, with special reference to the endocrine system. J. Nutr., 49, 397-423.

PELUFFO R. O., BRENNER R. R., 1974. Influence of dietary protein on 6- and 9-desaturation of fatty acids in rats of different ages and in different seasons. J. Nutr., 104, 894-900.

PETO R., PIKE M. C., ARMITAGE P., BRESLOW N. E., COX D. R., HOWWARD S. V., MANTEL N., MC PHERSON K., PETO J., SMITH P. G., 1977. Design and analysis of randomized clinical trials requiring prolonged observation of each patient. II. Analysis and examples. Br. J. Cancer, 35, 1-39.

PURVIS J. M., CLANDININ M. T., HACKER R. R., 1983. Chain elongation-desaturation of linoleic acid during the development of the pig. Implication for the supply of polyenoic fatty acids to the developing brain. Comp. Biochem. Physiol., 75, 199-204.

QUACKENBUSH F. W., KUMMEROW F. A., STEENBOCK H., 1942. The effectiveness of linoleic, arachidonic and linolenic acids in reproduction and lactation. J. Nutr., 24, 213-224.

RIVERS J. P. W., FRANKEL T. L., 1981. Essential fatty acid deficiency. Br. Med. Bull., 37, 59-64.

SANDERS T. A. B., NAISMITH D. J., 1980. The metabolism of linolenic acid by the foetal rat. Br. J. Nutr., 44, 205-208.

SINCLAIR A. J., CRAWFORD M. A., 1972. The accumulation of arachidonate and docosahexaenoate in the developing rat brain. J. Neurochem., 19, 1753-1758.

SINCLAIR A. J., CRAWFORD M. A., 1973. The effect of a low-fat maternal diet on neonatal rats. Br. J. Nutr., 29, 127-137.

SOKAL R. R., ROHLF F. J., 1969. Biometry, W. H. Freeman and Co. Ed., San Francisco and London.

TALBERT G. B., 1968. Effect of maternal age on reproductive capacity. Am. J. Obst. Gynec., $102,451-477$.

TINOCO J., 1982. Dietary requirements and functions of $\alpha$-linolenic acid in animals. Progr. Lipid Res., 21, 1-45.

TINOCO J., WILLIAMS M. A., HINCENBERGS I., LYMAN L., 1971. Evidence for the nonessentiality of linolenic acid in the diet of the rat. J. Nutr., 101, 937-945.

TURPEINEN O., 1938. Further studies on the unsaturated fatty acids essential in nutrition. J. Nutr., 15, 351-366. 